\title{
61. Communicating science beyond the ivory tower
}

\section{David R. Montgomery}

In college I never imagined that I'd spend a lot of time later in life writing about soil. Soil, after all, was the stuff that my professors told me to look past to study the more interesting rocks below. As it turned out, I gravitated toward the interface between geology and the living world, to the form of the land itself and geomorphology - the science of landscape evolution.

So, it became important to know what set the properties of the soil because that influenced how erosion shaped the land - what kind of landslides to expect where and how they'd behave, whether the soil would blow away with the wind if stripped of vegetation, or erode off in a few rainstorms if plowed. Understanding the soil came along for the ride in learning about the land.

Little did I know that years later soil would take me on an intellectual journey to explore how the way that people treated the land shaped how the land would treat their descendants. Eventually I came to see how reversing soil degradation could help address some of the largest and most daunting challenges humanity faces today - feeding the world, cooling the planet, and saving biodiversity. Now, in writing about what I learned along the way, I try to share insight and build support for changes I see as necessary to avoid calamity. But I didn't set out to become a writer.

For a decade after graduate school I did extensive fieldwork on erosion, rivers, landslides, and mountain range evolution that took me around the world, to Asia, South America, the Himalayas and Tibet. I studied sediment-choked rivers on the flanks of active volcanoes in the Philippines, floodplain sedimentation in the jungles of the upper Amazon, how wood-choked rivers in the rainforests of the Olympic Peninsula created ideal salmon habitat, and how clearcuts that harvested most trees in an area caused landslides on the steep rain-soaked slopes of the Pacific Northwest. I learned to work with new forms of digital topography and helped discover giant ancient floods that ripped through parts of Tibet and Alaska.

But it was understanding the ways that the changing nature of the landscape affected salmon populations in Europe, New England, and the Pacific Northwest that pulled me into writing for the general public. I began studying 
the effects of land use on river systems and the salmon that lived in them after taking a two-year temporary position at the University of Washington, where I still teach three decades later. After being invited by the governor's office to participate in an independent science panel to evaluate statewide salmon recovery plans, I started asking - and reading - about what had happened to salmon in Europe and New England. I thought it logical to assess whether there were lessons from the experience of those regions that would prove useful in the Pacific Northwest.

I did not plan on writing a book about it. Then I met an editor who was visiting an author on the faculty in the department where I'd just gotten tenure. She was not shy about looking for potential new authors and over lunch I pitched her a popular-science book about the environmental history of soil erosion. "You want to write a book about dirt? What else you got?" came her terse reply.

I responded with an apparently more appealing idea that became my first general-audience book, King of Fish: The Thousand-Year Run of Salmon (2003). In it I told the environmental history behind the decimation of Atlantic salmon runs and how the Pacific Northwest was repeating mistakes without learning clear lessons from the long history back east. Along the way, I learned that I liked writing for non-scientists. It was liberating as a writer not to be limited to the rigid hypothesis, methods, results, discussion, and conclusions format I'd become accustomed to following. Science, history, and experience could tell an engaging story if synthesized and woven together in a more reader-friendly way.

Soon after the book came out, an editor with another publisher asked me what my next one would tackle. I took a chance and once again suggested a history of how soil erosion affected human societies in the past. Little did I know that one of the editor's personal interests lay in archaeology. He was hooked, and soon so was I, spending nights and weekends for the next several years researching and writing Dirt: The Erosion of Civilizations (2007). In my travels, I'd noticed that impoverished peoples often inhabited regions with degraded soil, but I did not fully appreciate the global story until I dug into the archaeological literature and recognized a repeated pattern. Societies that did not take care of their land did not last.

Yet, curiously, there was a surprising villain to the tale - the plow. How did this icon of agriculture turn bad? Tillage leaves the land bare and vulnerable to erosion by wind and rain. And over time soil organic matter falls on newly tilled fields. While nature takes centuries to make an inch of topsoil, plowed fields can lose as much in decades. Over and over again throughout history farming practices degraded the fertility of the land - with devastating consequences. 
Writing King of Fish and then Dirt gave me a new window into natural resources management. I not only learned that I like delving into history, but I became intrigued by parallels in the broad arc of these environmental stories of natural resource mismanagement. A disturbing conclusion emerged regarding how societies can inadvertently degrade resources they value and depend on. A lot of the science we do know does not get used in setting policies and making decisions at a societal level. And all too often a short-term focus leads to policies and behaviors that cause damage over the long run.

Somewhat demoralized, but interested in developing as a writer, I next decided to indulge a personal interest in the tangled history of science and religion in regard to what shaped the world we know. Exploring the origin of the world's flood stories in The Rocks Don't Lie (2012), I looked into how geologists and theologians viewed the story of Noah's Flood. The historical dance of reason and faith turned out far more interesting than I'd suspected - some of humanity's oldest stories reflect our innate curiosity about what shaped the world we know. While our understanding of the nature of our world keeps changing, our fascination with it doesn't diminish.

But in the back of my mind I continued to wrestle with the problem that soil is a fundamental resource we take for granted and have destroyed time and again. I knew we couldn't afford to do so once again on a global scale - and that we were on track to doing just that. Identifying problems wasn't enough; identifying solutions was essential.

Inspiration came from an unexpected quarter. As I was finishing writing Dirt, my biologist wife was turning our back yard into a garden. Over the course of a few years she turned what started out as khaki, organic-matter-poor dirt with nary a worm into dark, rich soil supporting an explosion of life above ground. Looking into how her intensive composting and mulching pulled off this biological alchemy, she and I wrote The Hidden Half of Nature (Montgomery and Biklé, 2016), which explored the new microbial science behind how soil life supports the botanical world, and the parallels between the human gut and the rhizosphere - the life-filled zone around the roots of plants. New science pointed to a new way of seeing how cultivating beneficial life below ground holds the key to rapidly rebuilding soil fertility, and how cultivating beneficial life in our bodies could help stem the rising tide of chronic diseases.

Of course, this brought up more questions about soil. What would it take to restore healthy soil on working farms, and could it be done at scale? Could we reverse the historical pattern of soil degradation that had cursed ancient societies? These are questions I then set out to answer in Growing a Revolution (2017). Visiting farms around the world that had already brought degraded soils back to enviable productivity, I found that the common element among them was adopting practices based on three simple principles that radically reversed conventional agricultural philosophy through the combination of minimal 
disturbance of the soil (not tilling), keeping the ground covered with living plants (planting cover crops between cash crops), and growing a diversity of cash and cover crops. Some farmers and ranchers accelerated the process by also adopting regenerative grazing practices based on frequent movement of compact herds across the land - much like native herbivores once moved across the plains. I was particularly impressed by how practices based on these principles rapidly made a positive difference on both conventional and organic farms. But while the general principles translated from one region to another, farmers used a wide range of specific practices to implement them, adapting specific practices so as to be appropriate for their crops, climate, and tools.

This is not really a new thing. For centuries, farmers around the world have adopted practices to maintain or enhance the fertility of their land. Cover crops, planting legumes, and crop rotations are not new ideas (United States Department of Agriculture [USDA], 1938). What is new is the idea of coupling these practices to minimal soil disturbance, such as with no-till farming. This parallels other approaches rooted in a philosophy of improving soil health, like agroforestry, permaculture, and biodynamic practices. What is becoming clear is that we face a serious problem in how the dominant, now-conventional style of monoculture-oriented, tillage intensive, and chemistry-centric farming degrades the soil over the long run.

According to a United Nations report, global land degradation already negatively impacts the well-being of at least 3.2 billion people - more than a third of humanity (IPBES, 2018). Decades ago, Pimentel et al. (1995) estimated that a third of the world's cropland had been degraded since World War II, and that we lose another 0.5-1 percent (about 12 million ha) each year. More recently, a 2015 United Nations Food and Agriculture Organization report on the status of the world's soil resources related that soil erosion results in an ongoing annual loss of 0.3 percent of global crop yields, enough to reduce global harvests almost 10 percent by 2050 (FAO, 2015).

Of course, the problem is not just soil erosion. North American farmland has already lost half its soil organic matter (Baumhardt, Stewart and Sainju, 2015). While estimates of how much carbon can be returned to the soil in the form of organic matter through new agricultural practices vary greatly, doing so would benefit various efforts to rebuild soil fertility and soil organic matter (and thereby reduce atmospheric $\mathrm{CO}_{2}$ levels) (e.g., Lal et al., 2018), conserve terrestrial biodiversity, and improve farm profitability (LeCanne and Lundgren, 2018). Disagreements over just how much wider adoption of regenerative farming could contribute should not be taken as a reason to delay wider implementation of practices that can deliver improvements to each of these challenges.

Too often we think of science as new technologies and products to sell, and overlook opportunities to use new science to rethink our fundamental assump- 
tions and reshape conventional practices. To me, the overarching revelation of The Hidden Half of Nature and Growing a Revolution lay in how an entirely different agricultural strategy comes into focus when we look to the role of soil life in rebuilding soil health.

What emerged from this journey of personal discovery was a new framing of an old problem as recent science pulled together from disparate disciplines pointed the way to a more sustainable agriculture. Here was a new philosophy of agriculture that could reverse the environmental damage of conventional methods. It was a new story for agriculture.

Like it or not, there is tremendous value to the stories that frame how we see the world. For we are hard-wired to relate to the world through stories. I suspect that many thousands of years of campfires drilled it deep into the fabric of our brains.

New stories can help us rethink public myths like the oft-repeated proclamations that organic farming can't feed the world and that we'll all starve if we don't use a lot of synthetic nitrogen fertilizer. If we neglect the state of the soil, these bits of conventional wisdom sound entirely reasonable. Yet they ring hollow once you see the way that rebuilding soil fertility can change the equation - and the answer.

Do we need more scientists to try their hand at communicating to the general public? The web-based media don't really do it. Their format is too brief and content generally too shallow. Television and movies usually go sensationalist when they engage in science-themed shows about supervolcanoes!, mega-quakes!, and killer landslides! And, of course, industry tends to spin science in their favor when they can - or can get away with it. So does that mean we should just rely on journalists to convey science to the general public? Unfortunately, they all too often allow myths to pass as gospel and miss the significance of ideas behind the science.

While I've heard it said that communicating science to the public is too important to be left to scientists, I believe that communicating science to the general public is too important to be left to journalists and spin-meisters. Given the global environmental crossroads humanity is fast approaching we need more scientists to tell the story of what science means, why it's important, and what it means for what we should do. And while scientists should not decide policy, we should not be so shy about expressing our opinions in the policy arena. Although lots of scientists actively avoid making policy recommendations, scientists should not forfeit their voice in policy debates just because they're scientists.

Any credible, sober assessment of humanity's current trajectory would conclude that our global society needs to change a lot of things this century, and do so profoundly in agriculture and energy in particular. While scientists tend to specialize in a narrow disciplinary focus these days, there remains a huge need 
to synthesize and translate science we already know for the general public and policymakers - and do it in a readily digestible form at more than a superficial level. Unfortunately, too many scientists shy away from engagement in policy discussions, choosing to stay in their lane and considering such input as out of bounds.

It seems to me that the people who know the most about an issue probably have advice worth listening to in regard to deciding what to do about it. The voices of independent scientists should be amplified and brought into public discourse about policy and not squelched or muzzled as a matter of course. Those who understand how the world really works need to help both frame the issues of importance and publicly guide us to solutions that work, for us all - and for the future.

\section{REFERENCES}

Baumhardt, R.L., B.A. Stewart and U.M. Sainju, 2015. North American soil degradation: processes, practices, and mitigating strategies. Sustainability, 7, 2936-60.

Food and Agricultural Organization of the United Nations (FAO), 2015. Status of the World's Soil Resources. Edited by L. Montanarella et al. Rome: Food and Agricultural Organization of the United Nations.

Intergovernmental Science-Policy Platform on Biodiversity and Ecosystem Services (IPBES), 2018. Summary for Policymakers of the Thematic Assessment Report on Land Degradation and Restoration of the Intergovernmental Science-Policy Platform on Biodiversity and Ecosystem Services. Edited by R. Scholes et al. Bonn: IPBES Secretariat.

LaCanne, C.E. and J.G. Lundgren, 2018. Regenerative agriculture: merging farming and natural resource conservation profitably. PeerJ, 6, e4428.

Lal, R., P. Smith and H.F. Jungkunst et al., 2018. The carbon sequestration potential of terrestrial ecosystems. Journal of Soil and Water Conservation, 73, 145A-152A.

Montgomery, D.R., 2003. King of Fish: The Thousand-Year Run of Salmon. Boulder, CO: Westview Press.

Montgomery, D.R., 2007. Dirt: The Erosion of Civilizations. Berkeley, CA: University of California Press.

Montgomery, D.R., 2012. The Rocks Don't Lie: A Geologist Investigates Noah's Flood. New York: W.W. Norton.

Montgomery, D.R., 2017. Growing a Revolution: Bringing Our Soil Back to Life. New York: W.W. Norton.

Montgomery, D.R. and A. Biklé, 2016. The Hidden Half of Nature: The Microbial Roots of Life and Health. New York: W.W. Norton.

Pimentel, D., C. Harvey and P. Resosudarmo et al., 1995. Environmental and economic costs of soil erosion and conservation benefits. Science, 267, 1117-23.

United States Department of Agriculture (USDA), 1938. Soils and Men: Yearbook of Agriculture 1938. Washington, D.C.: United States Government Printing Office. 